\title{
TEMPORAL AND SPATIAL TRENDS OF TOTAL ALIPHATIC HYDROCARBONS OF DIESEL RANGE AND TRACE ELEMENTS IN SEDIMENTS AND MUSSELS OF THE CORRAL BAY AREA, VALDIVIA, SOUTH CENTRAL CHILE
}

\author{
HERNAN PALMA-FLEMING*, EDUARDO QUIROZ R., CLAUDIA CAMPILLAY, MAURICIO FIGUEROA, ALEX \\ VARAS, DOMINGO VELÁSQUEZ, BERNARDO JARA AND XIMENA PALMA-LARREA
}

\author{
Universidad Austral de Chile, Facultad de Ciencias, Instituto de Ciencias Químicas, Casilla 567, Valdivia, Chile. \\ Universidad Austral de Chile, Instituto de Química, Facultad de Ciencias, Casilla 567, Valdivia, Chile
}

(Received: October 22, 2010 - Accepted: January 31, 2012)

\begin{abstract}
Sediments and mussel specimens of Mytilus chilensis were analyzed for organic pollutant fingerprints and heavy metals in the Corral Bay area of Valdivia, South Central Chile during the period 2003-2004. GC-MS analysis show hydrocarbon fingerprints corresponding mainly to mixed inputs of aliphatic hydrocarbons of the TPH-diesel fraction and biogenic hydrocarbons, indicating low to medium contamination by petroleum hydrocarbons with high biodegradation of petroleum in sediments at Las Coloradas, La Escuela and Corral Bay $\left(\mathrm{C}_{17} / \mathrm{Pri}<1\right.$ and $\left.\mathrm{C}_{18} / \mathrm{Phy}<1\right)$. Mussel TPH fingerprints show weathered hydrocarbons resulting in a zone of increased concentration of cyclic respect to acyclic aliphatic components (UCM), indicating the presence of petroleum hydrocarbons. No temporal variation the in concentration of TPH-diesel found in sediments as well as mussels were observed except for samples collected during January 2004 . TPH concentration levels in the sediments varied from $0.4 \mu \mathrm{gg}^{-1}$ to $33.8 \mu \mathrm{gg}^{-1} \mathrm{~d}$.w. whereas in mussels varied between $61 \mu \mathrm{g} \mathrm{g}^{-1}$ and $_{28} 28 \mathrm{ggg}^{-1} \mathrm{~d}$.w. Heavy metals were also analyzed by atomic absorption spectrometry and low concentration as well as no seasonal variations of concentration were found in mussels at each sampling point and a relatively even distribution of metals among stations was observed. Maximum concentrations in all sampling points of sediments were found for Fe (24128-43791 $\left.\mu \mathrm{gg}^{-1}\right)$ and $\mathrm{Mn}\left(181-388 \mu \mathrm{gg}^{-1}\right)$ while the minimum concentration was found for Pb (nd-12 $\mu \mathrm{gg}^{-1}$ ). According to the Sediment Quality Guidelines (SQGs-NOAA), the concentration levels of $\mathrm{Cu}$ and $\mathrm{As}$ in all sediment sampling points are above the "Effects Range-Low" (ERL), indicating that there may be a probable toxicity effect over the biota and attention must be paid on a moderate range of priority.
\end{abstract}

\section{INTRODUCTION}

Estuaries are important and highly dynamic ecosystems that receive large amounts of natural and anthropogenic input, producing a variety of chemical and biological process and they are vital for the reproduction, growth and survival of numerous aquatic species. Bays that are directly connected to the mouth of estuaries are of special concern because most of the pollution that goes into the sea comes from river and coastal streams, producing important effects over the estuaries and living resources ${ }^{1}$. The main effect of the anthropogenic activities on the estuaries is the increasing mobilization of sediments, nutrients and particulate matter ${ }^{2}$.

To evaluate the effects of the pollution over these ecosystems is useful to determine the type of contamination (organic, inorganic, bacterial) as well as their potential sources to distinguish the specific origin of point or diffuse contamination since both are concentrated in the mouth of the estuaries and related areas. However, even thought all contributing sources would be known, it has been demonstrated that environmental investigations can be complex, because the composition of chemicals in the environment usually change over time by photolysis, biodegradation, volatilization and oxidation ${ }^{3}$. Among the most important pollutants, petroleum hydrocarbons and metals from industrial, municipal and sewage discharge and runoff coupled with aerial deposition are of particular concern due to their environmental persistence and wide range of toxicity effects over the aquatic biota, even for some of them at low concentrations ${ }^{4}$.

It has been demonstrated that Exploratory Data Analysis (EDA) is the best approach to identify chemical tracer or specific chemical fingerprints which could be associated to suspected sources for assessing cause-effect relationships ${ }^{5}$. Chemical fingerprints and chemical tracers have been successfully used to distinguish discrete fuel types ${ }^{6,7,8}$, fecal sterols sewage contamination ${ }^{9,10}$, particular solvents used as vapor degreasers, PCBs for age dating and source identification ${ }^{7}$ and Kraft pulp bleaching activities ${ }^{11}$. Oil fingerprinting as identification system is based on the analysis of chemical profile of even and odd carbon number distribution of aliphatic hydrocarbons that reflect the source of contamination and the weathering stage of the pollutant. Important organic chemical markers actually used in sediments as well in bivalves are total petroleum hydrocarbons (TPHs), straight chain saturated hydrocarbons ( $\mathrm{n}$-alkanes $\mathrm{C}_{10}-\mathrm{C}_{35}$ ), unresolved complex mix (UCM) and polycyclic aromatic hydrocarbons (PAHs) ${ }^{12}$.

Metals like $\mathrm{Cu}, \mathrm{Cr}, \mathrm{Fe}, \mathrm{Mn}, \mathrm{Pb}$ and the metaloid As from natural geological process as well anthropogenic activities are widely distributed in coastal environments and they are known to accumulate within the aquatic trophic chain $^{13}$. Metals in the aquatic environment are trapped into sediments ${ }^{14,15}$, while mussels accumulate trace elements in their soft tissue. Mussels are filter-feeders and thus obtain pollutants from food, water and particulate materials ${ }^{16}$. In this respect, since bivalve mollusks have a limited detoxification system, they have the tendency to bioaccumulate many of these xenobiotics and therefore they are widespread used as bioindicators for monitoring the concentration of pollutants around the world ${ }^{4}$. Heavy metals like $\mathrm{Pb}$ has been related to impacted areas by gasoline ${ }^{6}$ while $\mathrm{Cu}, \mathrm{Cr}$ and $\mathrm{As}$ have been related to fungicide formulations applied to wood chips and lumber products ${ }^{13,17}$.

The Corral Bay area, XIV Region of Chile, is located at the mouth of the Valdivia and Tornagaleones estuaries $\left(39^{\circ} \mathrm{S}, 73^{\circ} 18^{\prime} \mathrm{W}\right)$. The bay is about $15 \mathrm{~km}$ downstream of the Valdivia city, and during the last decades its environment has been altered mainly through anthropogenic influences ${ }^{18}$. More recently, the area has undergone dramatic changes due to increasing environmental-related activities that include waste water emissions, industrial and domestic solid and liquid wastes, aerial emissions, cattle and agriculture activities, intentional and unintentional oil spills from motor driven boats and ships. Furthemore, forest activities, periodical fumigations to control the pine moth, aerial transportation and deposition of Persistent Organic Pollutants (POPs), fluvial wood chips transportation, wood and paper industries, shipyards, fishing industries, salmon conditioning jails should be added as anthropogenic activities that influence over the Valdivia Estuary and related coastal area. A recent survey made by the present authors to local fisherman that have been affected by suspected pollution in the Corral Bay area reveals that mussels and oysters population density have dramatically decreased, in some areas being completely extinguished and when mussel seeds are arranged in different area for repopulation purposes, the specimens do not growth more than $2 \mathrm{~cm}$. abruptly dying. Pollution by polycyclic aromatic fraction of hydrocarbons (PAHs) in Mytilus chilensis at medium levels in the Corral Bay area (Carboneros and Puerto Claro) has been reported (medium polluted: $100-1100 \mathrm{ng} / \mathrm{g})^{19}$. During the years 2003 and 2004 TPH-diesel and PAHs were measured in sediments of the Valdivia River, being classified as medium to highly polluted, with TPH-diesel concentrations between 20 and $41 \mu \mathrm{gg}^{-1}$ dry weigh and total PAHs variation from 72 to 3122 $\mathrm{ngg}^{-1}$ dry weight (Palma-Fleming et al., in progress).

The aim of the current investigation was to examine sediments and mussels collected from known critical areas of the Corral Bay area of Valdivia to identify chemical fingerprints, organic tracers and selected heavy metals as well to determine temporal and spatial trends in the distribution of pollutants to assess the environmental health of the ecosystem. 


\section{EXPERIMENTAL}

\section{Sampling}

Three sampling campaigns, January 2004 (1), September 2004 (2) and January 2005 (3) were carried out in Las Coloradas (LC) (39 54'44's;

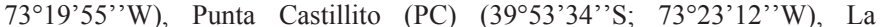
Escuelita (ES) (39 $53^{\prime} 13^{\prime}$ 'S; $73^{\circ} 21^{\prime} 47^{\prime}$ 'W), Bahía Corral (BC) (39 $52^{\circ} 08^{\prime}$ 'S; $\left.73^{\circ} 16^{\prime} 10^{\prime \prime} \mathrm{W}\right)$ and Las Canteras (LCan) (39 $\left.52^{\prime} 13^{\prime \prime} \mathrm{S} ; 7^{\circ} 22^{\prime} 44^{\prime \prime} \mathrm{W}\right)$ (Fig.1). A previous screening campaign during October 2003 was carried out to look for specific organic chemical tracers of contamination and to measure trace metals, including Arsenic. Sediments were collected according to Standard Operating Procedures (SOPs) described by the Environmental Protection Agency (U.S.EPA) ${ }^{20}$. Surface sediments with thickness between 10 and 20 $\mathrm{cm}$. were collected by triplicate $(\mathrm{n}=3)$ either by autonomous diving or by an Eckman grab depending on sediment characteristics. Autonomous diving was also used to collect triplicate samples $(n=3)$ of mussels from natural banks or culture farming. All samples were immediately transported to the laboratory and frozen until analysis. Samples of the first campaign were used only for screening purposes, except for trace metals. No trace metals were analyzed at Las Coloradas site since few specimens of Mytilus chilensis were collected during most of the campaigns as well as no specimens were found in La Escuela during January 2004.

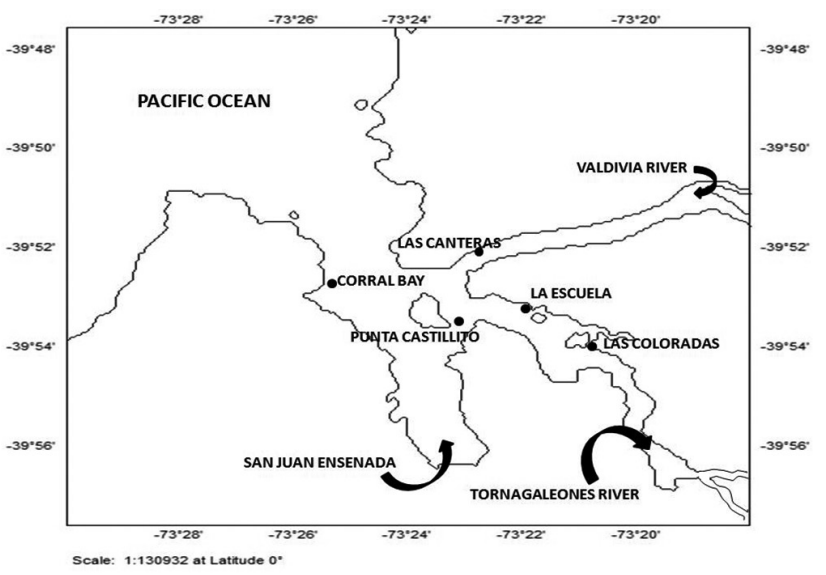

Fig.1. Sampling sites from Corral Bay area of Valdivia, South Central Chile.

\section{Analytical Methodology}

a) Screening analysis

Approximately $10 \mathrm{~g}$ of wet sediments were dried by mixing with anhydrous sodium sulphate and extracted with dichloromethane according to the Microscale Solvent Extraction method SW-846-3570 described by U.S.EPA ${ }^{21}$. Mussel samples were Soxhlet extracted with dichloromethane according to the methodology described by Granby and Spliid ${ }^{22}$ with the modifications described in $\mathrm{b}$ ). Succinctly, about $7 \mathrm{~g}$ of pooled fresh specimens were homogenized by an Ultra-Turrax tissumizer, dried by mixing with anhydrous sodium sulphate and then Soxhlet extracted with dichloromethane (nanograde, Merck) during approximately $8 \mathrm{~h}$ until completing a total of 40 cycles. The extract was evaporated to $1 \mathrm{~mL}$ and solvent exchanged by hexane. Screening analysis was achieved according to the United States Environmental Protection Agency (U.S.EPA) method 8270C ${ }^{23}$. A chromatograph HewletPackard HP 6890 equipped with a programmable temperature vaporizing inlet (PTV) and coupled to an HP 5973 mass selective detector (Hewlett-Packard, Palo Alto, CA, USA) in scan mode were used for fingerprint and chemical tracers search. The injector temperature was maintained at $280^{\circ} \mathrm{C}$ in a pulsed splitless mode. A GC program temperature ramp from $60{ }^{\circ} \mathrm{C}$ for 4 min., then at a rate of $10^{\circ} \mathrm{C} / \mathrm{min}$ up to $300^{\circ} \mathrm{C}$ was used to afford the best separation by using a capillary HP-5 MS column (Hewlet-Packard, Palo Alto, CA, USA).

Screening analysis was also performed in water samples collected during 2004-2005. Samples were analyzed by a combined solid-phase microextraction (SPME) and GC-MS according to methods described in the literature ${ }^{24,25}$. Succinctly, about $2 \mathrm{~mL}$ of water samples were extracted during 20 min by inmersion of a cleaned solid phase microfiber coated with a $100 \mu \mathrm{m}$ polydimethylsiloxane film (Supelco) and thereafter analytes were desorbed in the injector of the GC-MS for about $3 \mathrm{~min}$.

\section{b) TPH fingerprints}

The analytical method used in this study describes the procedure to analyze total petroleum hydrocarbons between $\mathrm{n}-\mathrm{C}_{10} \mathrm{y} \mathrm{n}-\mathrm{C}_{25}$, including oils and fuels. Around $10 \mathrm{~g}$ of wet sediments were extracted as indicated in a). The hexane extracts were further purified into aliphatic fractions by alumina-silica gel column chromatography and grains copper were added to each sample for sulfur elimination purposes ${ }^{23}$. The hexane extracts from mussel samples were saponified by refluxing for $2 \mathrm{~h}$ with $50 \mathrm{~mL}$ ethanol/KOH $1 \mathrm{M}$ and then the warm sample was transferred to a separatory funnel and $20 \mathrm{~mL}$ of $0.25 \mathrm{M}$ sulphuric acid was added. The neutralized aqueous solution was extracted three times with hexane and reduced to a volume of c.a. $1 \mathrm{~mL}$. Meanwhile water samples were liquid-liquid extracted ${ }^{25}$ and analyzed by U.S. EPA Method $8270 \mathrm{C}^{23}$. The final hexane extracts from mussel and water samples were purified in the same way as sediments samples, except that no copper was added to samples. Internal standard 1-chlorooctadecane (Supelco) was added to hexane extracts from each sample matrix for TPH calculations. GC-MSD equipment and chromatographic-mass spectrometry run conditions were the same as described in the exploratory analysis. Total Petroleum Hydrocarbons of diesel range (TPH-diesel) $\left(n-C_{10}\right.$ to $\left.n-C_{25}\right)$ was quantified in each sample by using a primary calibration standard mixture of modified underground storage dieselrange standard hydrocarbons $\mathrm{n}-\mathrm{C}_{10}$ to $\mathrm{n}-\mathrm{C}_{25}$ (UST, Supelco) and a commercial TPH-diesel as secondary standard.

Analytical protocols for sediment samples were validated by using certified reference material of n-alkanes in 2,2,4-trimethylpentane, SRM 1494 of the National Institute of Standards and Technology, U.S.A. (NIST). All samples were spiked with 2-Fluorobiphenyl prior to extraction for recovery calculations. The recoveries of TPH-diesel were between $80 \%$ and $120 \%$. The Relative Percent Difference (RPD) for analytical duplicates was less than 10 $\%$. Detection limits for individual hydrocarbons of TPH-diesel were $10 \mathrm{ngg}^{-1}$ d.w. and $100 \mathrm{ngg}^{-1}$ d.w. in the case of sediments and mussels respectively.

\section{c) Heavy metal analysis}

Sampling for metal analysis was achieved according to the U.S.EPA Method 823-B-01-002 (2001 $)^{26}$. Surface sediment samples were collected at 10 to $15 \mathrm{~cm}$ depth by autonomous diving or by means of glass core, depending on sediment characteristic.

An Atomic Absortion Spectroscopy (AAS) instrument UNICAM M-5 was used to determine the content of the different metals, $\mathrm{Cu}, \mathrm{Cr}, \mathrm{Fe}, \mathrm{Mn}$ and $\mathrm{Pb}$, however a Perkin Elmer 3110 AAS and a hydride generator Perkin-Elmer MHS-10 were used for Arsenic analysis.

Analytical protocols for mussel samples were validated by using DOLT4 (Dogfish Liver Certified Reference Material for Trace Elements) of the National Research Council Canada (NRC) and organics and trace metals for sediments SRM- 1944 (NIST).

\section{RESULTS AND DISCUSSION}

1-Bromonaphthalene was identified in all water samples from La Escuela site. This organohalogenated compound has been previously reported in environmental samples, and it has been detected as a contaminant in organobromine fire retardants ${ }^{27,28}$. This aromatic organobromine compound was not detected in the remaining sites and its origin could be attributed to intensive traffic of fluvial transportation of wood chips between the processing plant located upstream the Valdivia and Angachilla rivers and the Corral Bay.

Total TPH in sediments and mussels of the 5 sampling stations are shown in Table 1 . The highest levels of TPH in sediments were found in January 2004 and they are significantly different $(\mathrm{p}<0.05)$ from the concentration levels measured in September 2004 and January 2005. However, non significant differences of TPH concentrations were found in mussels among the three campaigns ( $\mathrm{p}>0.05$ ), except in Las Coloradas during January 2004 whose TPH level overpass 7 and 4 times the concentration levels during September 2004 and January 2005 respectively. La Escuela doubles the concentration level found in September 2004 compared to January $2005(p<0.05)$. Sampling points not showing concentration data mean that no specimens were found. Typical TPH chromatographic fingerprints found in mussels and sediments in this study are shown in Fig. 2 and 3; and a typical TPH chromatogram extracted at mass 57 for mussels is shown in Fig. 4. 
Table 1. The mean value of TPH concentration ( $\mu \mathrm{g} \mathrm{g}^{-1} \mathrm{~d}$.w.) in mussels $(\mathrm{m})$ (Mytilus chilensis) and sediments (s) samples collected by triplicate $(\mathrm{n}=3)$ during January 2004, September 2004 and January 2005 (sampling 1, 2 and 3, respectively) in the Corral Bay area, Valdivia, South Central Chile.

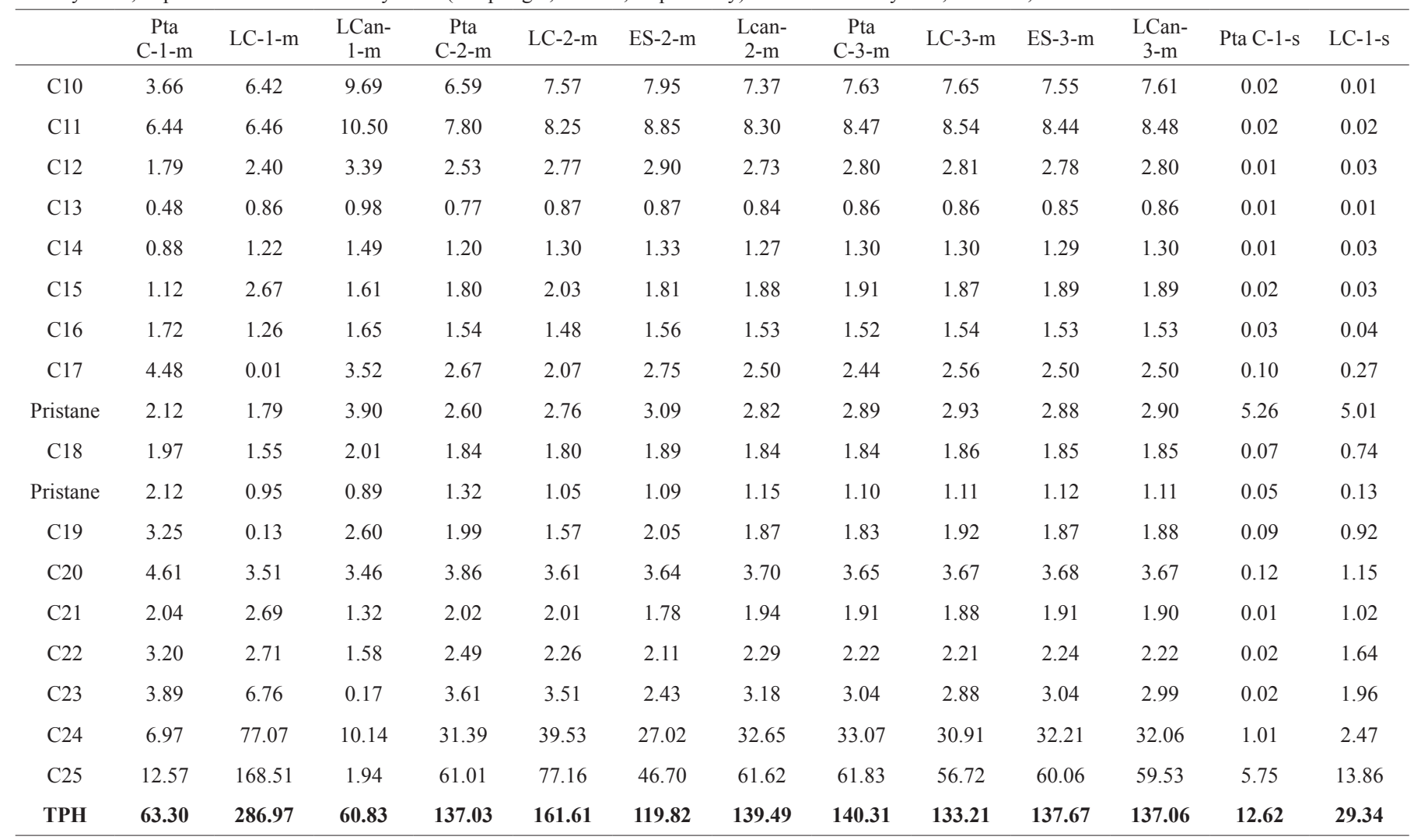

Note: First part of the acronyme Pta C-X-m (s), LC-X-m(s), LCan-X-m(s), ES-X-m(s), BC-X-m(s) refer to the sampling point as indicated in the sampling section, $\mathrm{X}$ indicates the campaign and $\mathrm{m}$ or s indicate mussels $(\mathrm{m})$ or sediments $(\mathrm{s})$.

Table 1 (continuation). The mean value of TPH concentration ( $\mu \mathrm{gg}^{-1} \mathrm{~d} . \mathrm{w}$.) in mussels (m) (Mytilus chilensis) and sediments (s) samples collected by triplicate $(\mathrm{n}=3)$ during January 2004, September 2004 and January 2005 (sampling 1, 2 and 3, respectively) in the Corral Bay area, Valdivia, South Central Chile.

\begin{tabular}{|c|c|c|c|c|c|c|c|c|c|c|c|c|c|}
\hline & $\begin{array}{c}\text { LCan- } \\
1-\mathrm{s}\end{array}$ & ES-1-s & BC-1-s & Pta C-2-s & LC-2-s & $\begin{array}{c}\text { LCan- } \\
2-\mathrm{s}\end{array}$ & ES-2-s & BC-2-s & Pta C-3-s & LC-3-s & $\begin{array}{c}\text { LCan- } \\
3-\mathrm{s}\end{array}$ & ES-3-s & BC-3-s \\
\hline $\mathrm{C} 11$ & 0.03 & 0.02 & 0.06 & 0.06 & 0.02 & 0.06 & 0.01 & 0.04 & 0.02 & 0.04 & 0.01 & 0.01 & 0.02 \\
\hline $\mathrm{C} 12$ & 0.01 & 0.02 & 0.06 & 0.01 & 0.01 & 0.05 & 0.01 & 0.01 & 0.01 & 0.02 & 0.01 & 0.01 & 0.01 \\
\hline $\mathrm{C} 13$ & 0.04 & 0.02 & 0.05 & 0.01 & 0.01 & 0.02 & 0.01 & 0.01 & 0.01 & 0.01 & 0.01 & 0.01 & 0.01 \\
\hline $\mathrm{C} 14$ & 0.04 & 0.05 & 0.05 & 0.01 & 0.01 & 0.06 & 0.01 & 0.04 & 0.01 & 0.04 & 0.01 & 0.01 & 0.02 \\
\hline $\mathrm{C} 16$ & 0.03 & 0.10 & 0.06 & 0.01 & 0.02 & 0.08 & 0.02 & 0.07 & 0.00 & 0.06 & 0.01 & 0.01 & 0.02 \\
\hline $\mathrm{C} 17$ & 0.15 & 0.25 & 0.16 & 0.01 & 0.10 & 0.10 & 0.00 & 0.11 & 0.02 & 0.07 & 0.01 & 0.07 & 0.03 \\
\hline Pristane & 0.32 & 4.66 & 0.44 & 0.04 & 0.06 & 0.13 & 0.04 & 0.17 & 0.02 & 0.12 & 0.02 & 0.01 & 0.05 \\
\hline $\mathrm{C} 18$ & 0.14 & 0.11 & 0.19 & 0.04 & 0.05 & 0.04 & 0.02 & 0.08 & 0.01 & 0.05 & 0.01 & 0.01 & 0.02 \\
\hline $\mathrm{C} 21$ & 0.96 & 0.74 & 1.30 & 0.01 & 0.01 & 0.01 & 0.12 & 0.23 & 0.15 & 0.12 & 0.03 & 0.47 & 0.10 \\
\hline $\mathrm{C} 22$ & 1.12 & 0.63 & 2.22 & 0.01 & 0.03 & 0.41 & 0.00 & 0.02 & 0.06 & 0.14 & 0.08 & 0.61 & 0.09 \\
\hline $\mathrm{C} 23$ & 2.47 & 3.66 & 4.27 & 0.01 & 0.09 & 1.03 & 0.01 & 0.04 & 2.40 & 0.36 & 0.01 & 1.60 & 0.92 \\
\hline $\mathrm{C} 24$ & 1.90 & 3.13 & 2.01 & 0.01 & 0.17 & 0.53 & 0.01 & 0.01 & 0.34 & 0.19 & 0.18 & 2.04 & 0.23 \\
\hline $\mathrm{C} 25$ & 16.79 & 16.70 & 20.57 & 0.03 & 0.59 & 3.18 & 0.04 & 0.09 & 0.41 & 1.10 & 0.47 & 8.43 & 0.66 \\
\hline ТРН & 25.84 & 30.43 & 33.83 & 0.82 & 1.44 & 6.33 & 0.42 & 1.73 & 3.65 & 2.82 & 0.95 & 13.39 & 2.47 \\
\hline
\end{tabular}




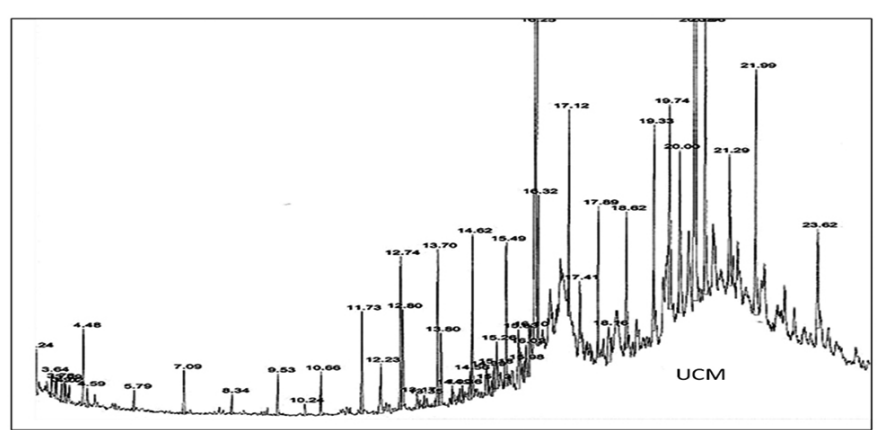

Fig. 2. A typical chromatographic fingerprint of TPH found in Mytilus chilensis collected from the Corral Bay area; the UCM include high molecular weight hydrocarbons other than petroleum hydrocarbons of diesel range.

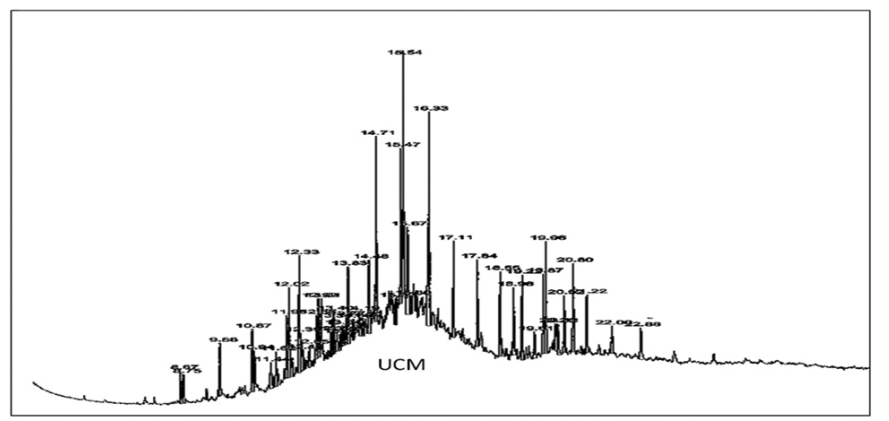

Fig. 3. A typical chromatographic fingerprint of TPH found in sediments collected from Las Coloradas at the Corral Bay area; the UCM of hydrocarbons is shown in the TPH-diesel range.

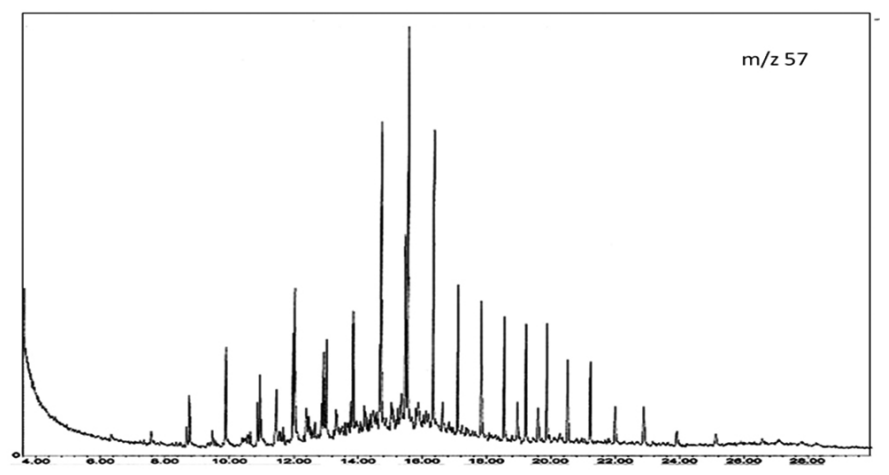

Fig. 4. Extracted ion at $\mathrm{m} / \mathrm{z} 57$ confirms the presence of TPH hydrocarbons in Mytilus chilensis collected from the Corral Bay area during 2004-2005.

\section{TPH}

\section{Sediments}

TPH found in sediments have a concentration range of 0.1-192.0 $\mu^{-1}$ and they compare well with the lowest concentration levels found in high contamination areas of petroleum refinery of Kuwait $\left(6.6-2066 \mu \mathrm{g} \mathrm{g}^{-1}\right)^{29}$ and it is also comparable to petroleum contaminated area of the Rio de la Plata Estuary, Argentina $\left(0.01-87 \mu \mathrm{g} \mathrm{g}^{-1}\right)^{30}$.

The presence of $n$-alkanes in aquatic biota and sediments has been widely used to identify possible sources of hydrocarbon contamination, mainly to distinguish between inputs from terrestrial higher plants, aquatic primary producers and petroleum-derived oils ${ }^{31-34}$. The TPH composition of petrogenic origin usually found in biota and estuarine sediments is complex and it is mainly characterized by a homogeneous alkane mixture of even and odd number of carbons having several homologous series of branched alcanes, cycloalkanes, isoprenoid alkanes and polycycloalkanes producing an unresolved complex mix (UCM) in the chromatogram of gas chromatography ${ }^{(22,34-37}$. In general, the UCM is considered to be associated with degraded or weathered petroleum residues, and unsaturated aliphatic hydrocarbons are not usually found in crude oils. It is known that biogenic hydrocarbons of recent origin exhibit relatively more simple fingerprints, characterized by a prevalence of n-alkanes of odd number of carbons and same alkenes associated to them ${ }^{12,35}$. All sediment chromatogram fingerprints in this study show an unresolved complex mix of hydrocarbons (UCM) from approximately $n-\mathrm{C}_{14}$ to $n-\mathrm{C}_{33}$ which represents a good evidence of an impacted area by weathered petroleum hydrocarbons ${ }^{12}$.

In addition to UCM and absolute concentrations, combined evaluation indices are generally used to evaluate the probable origin of hydrocarbons to reinforce the understanding of either biogenic, anthropogenic or mixtures of both inputs, however interpretations must be carefully handled due to the multiple source that may be contributing to hydrocarbon mixtures in environmental compartments, particularly at low concentrations of hydrocarbons. Some evaluation indices selected in this study, and well defined in the literature ${ }^{38}$, Pri/ Phy (Pristane/Phytane ratio), $\mathrm{C}_{17} /$ Pri (n-Heptadecane/Pristane ratio), $\mathrm{C}_{18} / \mathrm{Phy}$ (n-Octadecane/Phytane ratio), $\Sigma \mathrm{C} / \sum \mathrm{C}$ (even to odd carbon number ratio) and Carbon Preference Index $\left(\mathrm{CPI}=0.5\left(\left(\mathrm{C}_{17}+2 \mathrm{C}_{19}+2 \mathrm{C}_{21}+2 \mathrm{C}_{23}+\mathrm{C}_{25}\right) /\left(\mathrm{C}_{18}\right.\right.\right.$ $\left.+\mathrm{C}_{20}+\mathrm{C}_{22}+\mathrm{C}_{24}\right)$ ) are shown in Table 2 . The pristane/phytane ratio, commonly used as an indicator for oxic and anoxic sedimentation, is usually larger in biogenic than in petroleum impacted sites $^{39}$. In the present study values from the 2004 campaign were abnormally high and varied between 1.71 and 98.55 , but it is remarkable that the highest values were observed in the inner side of the Corral Bay (Punta Castillito, Las Coloradas and La Escuela) (Fig.1), suggesting a strong influence of biogenic origin, probably produced by imputs of terrestrial plants residues. However the ratio $\mathrm{C}_{17} /$ pristane $\left(\mathrm{C}_{17} /\right.$ pri) and $\mathrm{C}_{18} /$ phytane $\left(\mathrm{C}_{18} / \mathrm{phy}\right)$, which usually show higher ratios in biogenic rather than in petrogenic contaminated samples ${ }^{12,22,40,41}$ were low, indicating significant level of petroleum input in the area. TPH usually shows a homogeneous distribution of even and odd carbon number n-alkanes, however in terrestrial plant waxes oddnumber n-alkanes are 8-10 times higher than even-number carbon n-alkanes ${ }^{42}$. According to this, the even-to-odd ratio index defined as $\sum \mathrm{C}_{\text {even }} / \sum \mathrm{C}_{\text {odd }}$ ratio for biogenic-terrestrial sources are characterized by values $<1$ while petroleum sources have ratios around one $e^{33}$. All samples from the first campaign (2004) showed a ratio $\sum \mathrm{C} / \sum \mathrm{C}<1$, except Punta Castillito, indicating biogenicterrestrial input. On the other hand, the CPI index in this study varied between 0.74 and 5.65, being Punta Castillito (second campaign) the only site for which, according to calculated CPI, suggest an input of petroleum hydrocarbons, while the remaining sites showed dominance of CPI $>1$, suggesting in these cases a biogenic input of hydrocarbons generally combined with high biodegradation of petroleum at Las Coloradas, La Escuela and Corral Bay according to $\mathrm{C}_{17} /$ Pri $<1$ and $\mathrm{C}_{18} /$ Phy $<1$ indices ${ }^{33}$. Probably, there may be other alternative sources of pristane precursors different than biogenic-terrestrial, like algae and zooplankton ${ }^{30}$. For the second campaign, Las Coloradas site showed $\mathrm{C}_{17} / \mathrm{Pri}>$ 1 and $\mathrm{C}_{18} / \mathrm{Phy}>1$ indices, indicating fresh input of petroleum oils ${ }^{43}$. However, other sites like Punta Castillito and La Escuela (third campaign) showed $\mathrm{C}_{17} / \mathrm{Pri}$ $>1$ and $\mathrm{C}_{18} / \mathrm{Phy}<1$ indices, indicating reductive condition that favors Phytane formation ${ }^{32}$. The ratio corresponding to the even-odd number of carbon around 1:1 suggest petroleum inputs and it is well known that source identification would be very difficult when the complex mixture of polycyclic hydrocarbons (UCM) of weathered petroleum becomes a dominant feature of the saturated hydrocarbon fraction ${ }^{12}$. Seasonal variation of TPH was observed in all sampling sites. The highest levels of TPH concentrations observed in samples collected during January 2003 were significantly different $(p<0.05)$ compared to the concentration levels of the remaining seasonal sampling and a tendency to dissipate was observed, probably due to natural or anthropogenic dynamic flux of organic matter.

Mussels

Mussel TPH fingerprints show weathered hydrocarbons resulting in a zone of increased concentration of alicyclic respect to aliphatic components (UCM). The presence of a prominent UCM is normally taken to indicate the presence of petroleum hydrocarbons ${ }^{22,44}$. Total ion current chromatogram (TIC) extracted at mass 57 support the presence of TPH (see Fig 4). The highest levels of TPH in mussels were found during $2004\left(61-287 \mu \mathrm{g} \mathrm{g}^{-1} \mathrm{~d}\right.$.w.) which is coincident with the highest levels found in sediments, and they are higher than chronically mildly polluted areas such as Todos os Santos Bay $\left(42 \mu \mathrm{g} \mathrm{g}^{-1}\right)^{45}$ and Sepetiba Bay, Brasil $\left(0.26-2.65 \mu \mathrm{g} \mathrm{g}^{-1}\right)^{46}$. Westernport, Australia $\left(126 \mu \mathrm{gg}^{1}\right)^{47}$, Narragansett Bay, Rhode Island $\left(42 \mu \mathrm{g} \mathrm{g}^{-1}\right)^{48}$, the Amposta Offshore Oil Production Plataform, Western Mediterranean $\left(40 \mu \mathrm{g} \mathrm{g}^{-1}\right)^{49}$ and Gulf of Naples $\left(48 \mu \mathrm{gg}^{-1} \text { wet weight }\right)^{50}$. However, TPH levels in this study $\left(24-115 \mu \mathrm{gg}^{-1}\right.$ wet weight, on a $60 \%$ humidity average basis) are lower than the reported levels found in mussels (262 $\mu g^{-1}$ wet weight) from sites of high contamination following large oil spills such as the "Arrow" oil spill in Chedabucto Bay, Nova Scotia, Canada ${ }^{51}$ and the reported levels in the Pearl River Estuary, China (1.7$2345.4 \mu \mathrm{g} \mathrm{g}^{-1}$ dry weight $)^{52}$. 
Table 2. Evaluation indices of aliphatic hydrocarbons in surface sediment of Corral Bay area, Valdivia, Chile.

\begin{tabular}{|c|c|c|c|c|c|c|c|}
\hline Sampling site & Campaign & Pri/Phy & C17/Pri & C18/Phy & $\sum \mathrm{C}_{\text {even }}$ & $\sum \mathrm{C}_{\text {odd }}$ & CPI \\
\hline & 1 & 98.51 & 0.02 & 1.30 & 6.52 & 6.02 & 2.5 \\
\hline \multirow[t]{3}{*}{ Punta Castillito } & 2 & 1.00 & 0.33 & 1.24 & 0.20 & 0.20 & 0.74 \\
\hline & 3 & 0.38 & 1.27 & 0.01 & 3.06 & 3.06 & 5.65 \\
\hline & 1 & 39.62 & 0.05 & 0.84 & 10.51 & 18.83 & 1.83 \\
\hline \multirow[t]{3}{*}{ Las Coloradas } & 2 & 2.43 & 1.63 & 1.49 & 2.62 & 8.07 & 1.84 \\
\hline & 3 & 2.69 & 0.22 & 0.48 & 2.01 & 10.22 & 2.26 \\
\hline & 1 & 33.18 & 0.05 & 0.76 & 8.79 & 21.64 & 3.36 \\
\hline \multirow[t]{3}{*}{ La Escuela } & 2 & 1.65 & 0.01 & 0.52 & 0.19 & 0.22 & 2.91 \\
\hline & 3 & 0.50 & 5.00 & 0.01 & 0.32 & 0.07 & 2.37 \\
\hline & 1 & 2.87 & 0.46 & 1.25 & 4.96 & 20.88 & 3.65 \\
\hline \multirow[t]{3}{*}{ Las Canteras } & 2 & 6.19 & 0.71 & 1.13 & 1.70 & 4.62 & 2.40 \\
\hline & 3 & 2.67 & 0.67 & 0.37 & 0.38 & 0.55 & 0.91 \\
\hline & 1 & 1.71 & 0.35 & 0.73 & 6.90 & 26.92 & 3.62 \\
\hline \multirow[t]{2}{*}{ Corral Bay } & 2 & 1.75 & 0.63 & 2.61 & 1.26 & 2.21 & 1.66 \\
\hline & 3 & 1.19 & 0.64 & 0.77 & 8.56 & 7.74 & 3.22 \\
\hline
\end{tabular}

There is no maximum concentration levels of TPH allowed in mussels neither suggested protective levels and little is known about toxic effects of the aliphatic fraction of hydrocarbons. Being highly hydrophobic, they bound to biota and it is already demonstrated that may cause adverse biological effects regardless quality criteria are not exceeded ${ }^{53}$. It has been reported that the more toxic fraction corresponds to the polycyclic aromatic hydrocarbons $(\mathrm{PAHs})^{54}$ 56. However, chronic toxicity of UCM on biota exposed to contaminated sediments has been reported, where the UCM-dominated oils could have impact by reducing population level of amphipods, even at concentration that do not affect survival (500 mugg $^{-1}$ dry weight spiked in sediments) ${ }^{57}$. It has been reported that the rate of production of feces and pseudofeces by oysters diminish with an increasing hydrocarbon concentration in water, reaching zero at $900 \mu \mathrm{g} \mathrm{mL} \mathrm{m}^{-1}$ concentrations, and at this level of concentration oysters remained closed ${ }^{58}$. Most mussel specimens in the present study were found dead with their valve closed, and this observation is coincident with the observation reported by the above authors. It has also been reported that TPH-diesel is more toxic than other crude petroleum oils on benthic species ${ }^{59}$.

Table 3 reveals that, according to Pri/Phy ratio $<1$ or near to 1 , aliphatic hydrocarbons content of mussel samples are probably from petrogenic sources. The C17/Pri and C18/Phy are low, confirming a significant contribution of petroleum input, with the exception of Punta Castillito (campaign 1) and La Escuela (campaign 3), both of them showing $\mathrm{C} 17 /$ Pri $>1$, and indicating for these two sites that biogenic contributions are derived from phytoplankton, because $\mathrm{C}_{17}$ is predominant in lipids of algae $\mathrm{e}^{30,44}$. Finally, the CPI indices for mussels were around 1 in all campaigns and sampling sites, thus confirming a probable contamination by petroleum hydrocarbons.

PCA Analysis

PCA analysis was applied to TPH composition of sediments and mussels for sampling sites and temporal variability. The first two components account for $66 \%$ of the total variance, $49 \%$ the first and $17 \%$ the second one. The first group, as principal contributor to PC1 (49\%) of the loading scatter plot (Fig. 5) is a group composed by hydrocarbons $\mathrm{C}_{10}$ to $\mathrm{C}_{21}$, pristane and phytane $(\mathrm{PC} 1+, \mathrm{PC} 2+)$ mainly due to estuarine spatial clustering corresponding to sediments and mussels collected during the second and third campaign, as shown by the score plot (Fig. 6). This suggest a relatively high positive loading of low to medium molecular weight n-alkanes $\left(\mathrm{C}_{10}-\mathrm{C}_{21}\right)$, attributed to petroleum hydrocarbon sources. A negatively correlated contribution to $\mathrm{PC} 1$ and $\mathrm{PC} 2$ of a highly scattered second group of n-alkanes $\mathrm{C}_{20}$ to $\mathrm{C}_{25}$ (PC1-, PC2- and $\mathrm{PC} 2+$ ) is observed (Fig. 5) and the score plot (Fig. 6) suggest hydrocarbons associated to sediments mainly from the first campaign composed of n-alkanes of different origin as compared to the first group, probably of diagenic and bacterial origin. This PCA show opposition between sampling sites of petrogenic inputs and biogenic sources as shown in the PCA score plot (Fig. 6). Since all chromatograms of sediments and mussels samples have a marked UCM (Fig. 2, 3, 4), it is highly probable that the origin of the hydrocarbons in this study corresponds not only to a mixing of diagenic and bacterial but also to petrogenic hydrocarbons as important components. However, since sediment samples collected during January 2004 are clearly separated from all other samples, hydrocarbon composition of this campaign may be associated to an event which was not registered in the other two groups. Weathering of aliphatic hydrocarbons is a complex process and in most cases, even if many different parameters reported in the literature may be used to discriminate origin, it is a difficult task to assess a specific input unless recent contamination has been occurred or specific sources of contamination would be precisely identified around the area under study. 
Table 3. Evaluation indices of aliphatic hydrocarbons in mussels of Corral Bay area, Valdivia, Chile.

\begin{tabular}{|c|c|c|c|c|c|c|c|}
\hline Sampling site & Campaign & Pri/Phy & C17/Pri & C18/Phy & $\sum \mathrm{C}_{\text {even }}$ & $\sum \mathrm{C}_{\text {odd }}$ & CPI \\
\hline \multirow{3}{*}{ Punta Castillito } & 1 & 1.00 & 2.11 & 0.93 & 74.37 & 102.80 & 1.06 \\
\hline & 2 & 3.00 & 0.65 & 0.75 & 50.54 & 64.61 & 1.00 \\
\hline & 3 & 0.49 & 2.06 & 0.25 & 57.04 & 66.94 & 0.95 \\
\hline \multirow{3}{*}{ Las Coloradas } & 1 & 1.89 & 0.10 & 1.64 & 288.40 & 564.27 & 1.11 \\
\hline & 2 & 1.31 & 0.58 & 0.64 & 52.04 & 40.24 & 0.99 \\
\hline & 3 & 1.79 & 0.67 & 0.54 & 85.33 & 95.71 & 0.94 \\
\hline \multirow{3}{*}{ La Escuela } & 1 & ns & ns & $\mathrm{ns}$ & $\mathrm{ns}$ & ns & $\mathrm{ns}$ \\
\hline & 2 & 0.99 & 0.37 & 0.28 & 117.49 & 250.58 & 0.89 \\
\hline & 3 & 0.69 & 4.08 & 0.44 & 92.25 & 105.12 & 0.95 \\
\hline \multirow{3}{*}{ Las Canteras } & 1 & 4.39 & 0.90 & 2.27 & 100.24 & 67.89 & 0.40 \\
\hline & 2 & 1.14 & 0.58 & 0.10 & 91.75 & 117.36 & 0.96 \\
\hline & 3 & 1.34 & 0.94 & 0.82 & 45.92 & 37.32 & 0.95 \\
\hline
\end{tabular}

ns: no samples found

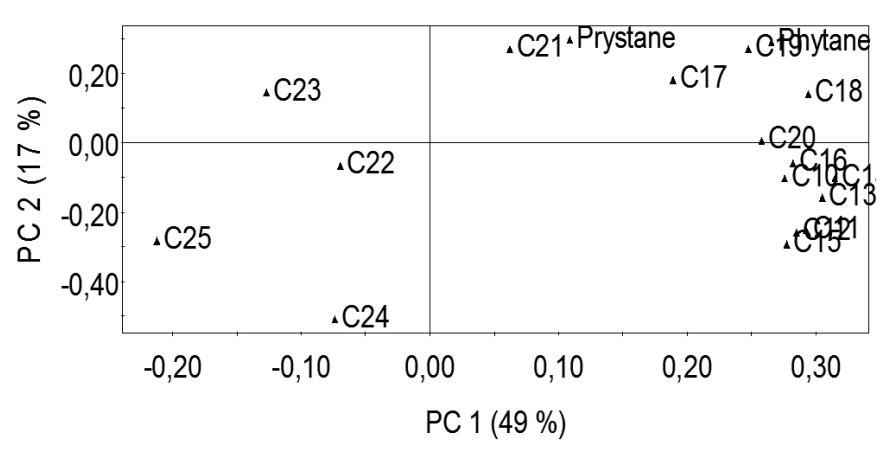

Fig. 5. PCA loading scatter plot showing spatial and temporal variability of aliphatic hydrocarbons in sediments and mussels collected in the Corral Bay area during 2004-2005, Valdivia, Chile.

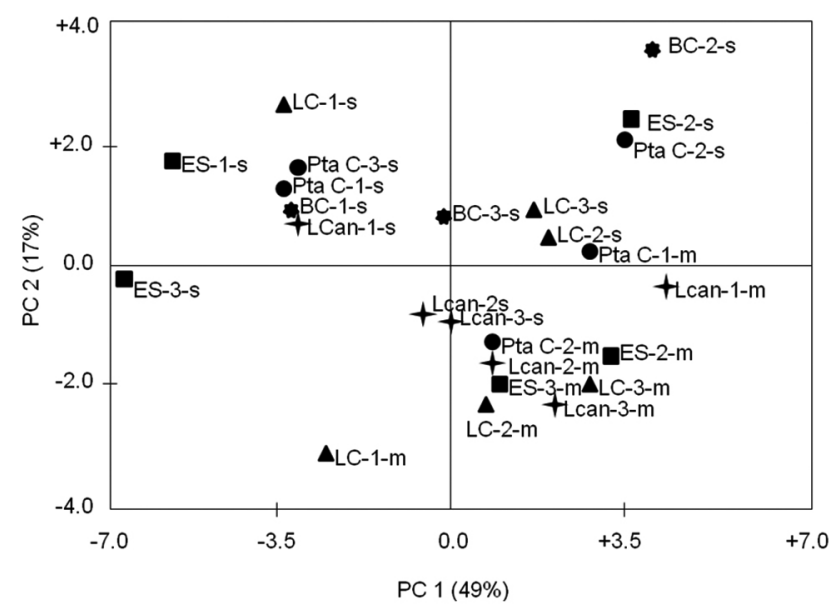

Fig. 6. PCA score plot showing estuarine spatial and temporal clustering of aliphatic hydrocarbons corresponding to sediments and mussels collected in the Corral Bay area during 2004-2005, Valdivia, Chile.

\section{Heavy Metals}

Heavy metals in sediments and mussels are shown in Table 4. Maximum concentrations in all sampling points of sediments were found for Fe (2412$\left.43791 \mu \mathrm{g} \mathrm{g}^{-1}\right)$ and $\mathrm{Mn}\left(181-288 \mu \mathrm{g} \mathrm{g}^{-1}\right)$ while the minimum concentration was found for $\mathrm{Pb}\left(<\mathrm{LD}-12 \mu \mathrm{g} \mathrm{g}^{-1}\right)$. Among metals analyzed in mussels, the highest concentration was found for Fe (145-388 $\left.\mu \mathrm{g} \mathrm{g}^{-1}\right)$ in all sampling points from which surviving specimen could be collected.

According to the sediment quality criteria of the Environmental Protection Agency of the United States of America (U.S. EPA), $\mathrm{Cu}$ and $\mathrm{Cr}$ are at the acceptance limit between not contaminated and moderately contaminated sediments in waters of rivers and lakes ${ }^{60}$. However, alternative non-regulatory guidelines, the Sediment Quality Guidelines (SQGs) developed for the National Status and Trends Program of the National Atmospheric and Oceanographic Administration of the United States of America (NOAA) ${ }^{61}$ have been used as informal interpretative tools by NOAA to identify areas and chemicals of specific environmental concern to warrant further detailed studies about actual toxic adverse effects. According to these guidelines, the concentration levels of $\mathrm{Cu}$ and $\mathrm{As}$, but not $\mathrm{Cr}$, in most of the sediment sampling points were above the "Effects Range-Low" (ERL) (the estimated "safe" concentrations below which adverse effects rarely occur), indicating that there may be a probable toxicity effect over the mussels and attention must be paid on a moderate range of priority. Although most trace elements show an even temporal and spatial distribution, $\mathrm{Cu}$ and $\mathrm{As}$ are the only two elements whose concentration values were between the ERL and ERM (Effects Range-Median) guideline values, meaning that the probability of incident of adverse effects are about $29 \%$ and $11 \%$ for $\mathrm{Cu}$ and As respectively (Fig. 7 and Fig. 8) ${ }^{61}$. It must be emphasized that these probabilities of incidence afforded by SQGs are only used as reference information, since bioavailability should be considered as an important factor when considering toxic adverse effects of in-situ chemical exposure to biota ${ }^{62}$.

No seasonal variations for heavy metals were found in mussels at each sampling point and relatively even distribution of each metal among sampling points was observed. Fe was found at higher concentration (145-388 $\left.\mu \mathrm{g} \mathrm{g}^{-1}\right)$ than values reported by Astorga et al. $\left(<0.1-60 \mu \mathrm{g} \mathrm{g}^{-1}\right)$ in Mytilus chilensis from the Strait of Magallanes ${ }^{63}$, and also higher than values reported by Yeats et al. in mussels from Halifax Harbour, Nova Scotia, Canada $\left(21 \mu \mathrm{g} \mathrm{g}^{-1}\right)^{64}$. All other heavy metals, including the metalloid As, are at low concentrations and their levels are similar to the levels found in other sites of chronic contamination, like in coastal areas of Bohai Sea, North China ${ }^{65}$. 


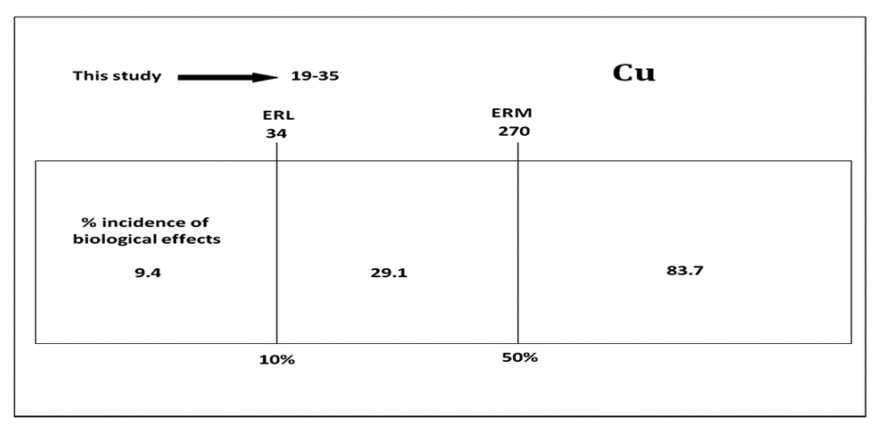

Fig.7. ERL and ERM guideline values for Copper ( $\mu \mathrm{g} \mathrm{g}^{-1}$ dry weight) and percent incidence of biological effects in concentration ranges defined by the two values (NOAA. U.S.A.) ${ }^{48}$. ERL $=$ Effects Range-Low; ERM $=$ Effects Range-Median.

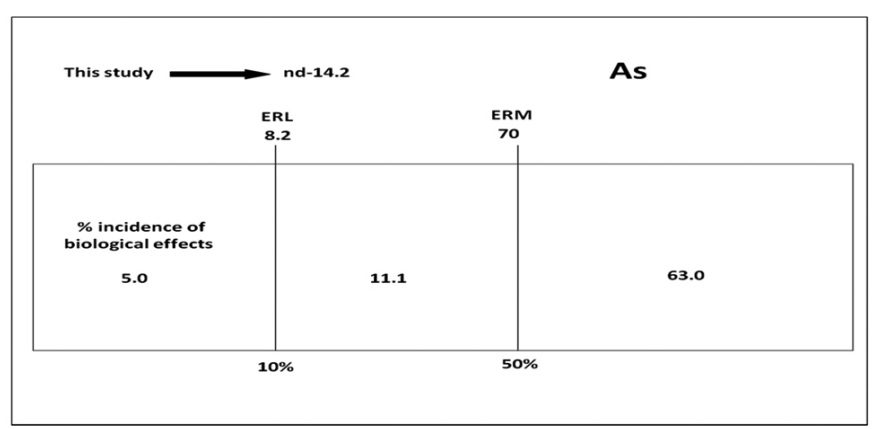

Fig. 8. ERL and ERM guideline values for Arsenic ( $\mu \mathrm{g} \mathrm{g}^{-1}$ dry weight) and percent incidence of biological effects in concentration ranges defined by the two values (NOAA. U.S.A.) ${ }^{48}$. ERL $=$ Effects Range-Low; ERM $=$ Effects Range-Median.
The concentration levels of $\mathrm{Cu}$ found in the mussel Mytilus chilensis in this study were between $1.7 \mu \mathrm{g} \mathrm{g} \mathrm{g}^{-1}$ and $4.0 \mu \mathrm{g} \mathrm{g}^{-1}$ and they are slightly lower than concentration levels previously found during the year 2000 for mussels in the same area of study (7.3-9.6 $\left.\mathrm{g} \mathrm{g} \mathrm{g}^{-1}\right)^{66}$ and the findings of Yap et al. (2004) in the green-lipped mussel Perna virides collected in the west coast of Peninsular Malaysia (7.8-20.1 $\mu \mathrm{g}$ $\mathrm{g}^{-1}$ dry weight $)^{67}$. However, $\mathrm{Cu}$ concentration levels in this study were in the range of concentration reported in Mytilus chilensis collected in the Strait of Magallanes, Chile $\left(0.8-4.7 \mu \mathrm{g} \mathrm{g}^{-1}\right)^{63}$. Reports about specific heavy metal toxicity on mussels are scarce. There are no scientific reports about Fe toxicity levels in mussels around the world, neither in specimens collected in coastal areas of Valdivia. However, aquatic toxicity of $\mathrm{Cu}$ is well studied on other species from United Kingdom estuaries ${ }^{68}$ for which there is experimental evidence that show sensitivity to dissolved concentrations as low as 1-10 $\mu \mathrm{g} \mathrm{L}^{-1}$. Besides the natural occurrence of $\mathrm{Cu}$ in aquatic environments, anthropogenic activities may supply additional inputs resulting in an increasing bio-availability of this metal; copper sulphate has been used as antifouling in vessel paints ${ }^{69}$ and for preservation of fish nets used in marine aquaculture. Copper is an essential element to life but it is also among the most toxic heavy metals ${ }^{70,71}$. It is well known the use of copper sulphate as antifouling in the Chilean salmon culture industry. Punta Castillito, La Escuela and Las Coloradas are located in shallow waters near to juvenile salmon conditioning jails, however Corral Bay and Las Canteras sites are located far away, at an area of greater water exchange due to tidal oscillations. Conditioning jails of juvenile salmon has been installed in the past 10 years and some of them are actually operating between La Escuela and Punta Castillito sites. Since 2008 the conditioning operations of salmon culture has been going under depletion mainly due to ISA virus epidemic disease. In addition to this source of metal pollutants, intensive transport of wood chips impregnated with NP-1, an antifungal formulation that contain $\mathrm{Cu}, \mathrm{Cr}$ and $\mathrm{As}$, has to be included as an important activity across the estuarine system.

\section{CONCLUSIONS}

Sediments and mussel specimens of Mytilus chilensis were analyzed for organic pollutant fingerprints and heavy metals in the Corral Bay area of Valdivia, South Central Chile. GC-MS analysis show hydrocarbon fingerprints corresponding mainly to mixed inputs of aliphatic hydrocarbons of the TPH-diesel fraction and biogenic hydrocarbons, indicating low to medium contamination by petroleum hydrocarbons with high biodegradation of

Table 4. Mean value of heavy metals and Arsenic ( $\mu \mathrm{g}$ g-1 p.s.) in sediments for triplicate field samples $(\mathrm{n}=3)$ and Mytilus chilensis $(\mathrm{n}=3)$ from different sites of the Corral Bay area (2003-2005).

\begin{tabular}{|c|c|c|c|c|c|c|c|c|c|c|c|c|c|c|c|c|c|c|c|c|c|c|c|c|}
\hline \multirow[t]{2}{*}{ Sediment } & \multicolumn{4}{|c|}{ Arsenic } & \multicolumn{4}{|c|}{ Copper } & \multicolumn{4}{|c|}{ Cromium } & \multicolumn{4}{|c|}{ Iron } & \multicolumn{4}{|c|}{ Manganese } & \multicolumn{4}{|c|}{ Lead } \\
\hline & 1 & 2 & 3 & 4 & 1 & 2 & 3 & 4 & 1 & 2 & 3 & 4 & 1 & 2 & 3 & 4 & 1 & 2 & 3 & 4 & 1 & 2 & 3 & 4 \\
\hline $\begin{array}{c}\text { Las } \\
\text { Coloradas }\end{array}$ & 10.9 & 11.6 & 12.6 & 14.2 & 21.0 & 35.4 & 27.5 & 35.1 & 20.3 & 26.9 & 24.6 & 26.2 & ns & ns & 39704 & 43370 & ns & ns & 225.3 & 295.5 & 5.8 & 8.2 & 4.9 & 6.7 \\
\hline $\begin{array}{c}\text { La } \\
\text { Escuelita }\end{array}$ & 9.7 & 11.0 & 13.1 & 12.3 & 28.4 & 25.5 & 24.5 & 32.2 & 28.5 & 23.2 & 20.3 & 23.4 & ns & ns & 37655 & 38524 & ns & ns & 230.1 & 248.9 & 7.7 & 6.0 & 5.7 & 6.6 \\
\hline $\begin{array}{c}\text { Pta } \\
\text { Castillito }\end{array}$ & 9.6 & 12.4 & 12.3 & 11.2 & 32.1 & 31.4 & 19.1 & 29.6 & 36.6 & 27.2 & 17.4 & 21.8 & ns & ns & 34712 & 37068 & ns & ns & 216.5 & 207.0 & 6.9 & 8.6 & 5.1 & 6.5 \\
\hline $\begin{array}{c}\text { Bahía de } \\
\text { Corral }\end{array}$ & 6.2 & 10.1 & 10.0 & 8.2 & 20.9 & 33.9 & 31.6 & 19.3 & 24.6 & 28.9 & 31.8 & 12.9 & $\mathrm{~ns}$ & ns & 43791 & 24128 & ns & ns & 261.0 & 180.8 & 8.0 & 12.4 & 11.2 & 4.9 \\
\hline $\begin{array}{c}\text { Las } \\
\text { Canteras }\end{array}$ & nd & 11.7 & 10.1 & 11.4 & ns & 30.6 & 21.1 & 28.3 & ns & 23.2 & 22.3 & 20.4 & ns & ns & 30877 & 36313 & ns & ns & 205.7 & 388.0 & ns & 9.0 & 4.8 & 4.5 \\
\hline \multirow[t]{2}{*}{$\begin{array}{c}\text { Mytilus } \\
\text { chilensis }\end{array}$} & \multicolumn{4}{|c|}{ Arsenic } & \multicolumn{4}{|c|}{ Copper } & \multicolumn{4}{|c|}{ Cromium } & \multicolumn{4}{|c|}{ Iron } & \multicolumn{4}{|c|}{ Manganese } & \multicolumn{4}{|c|}{ Lead } \\
\hline & 1 & 2 & 3 & 4 & 1 & 2 & 3 & 4 & 1 & 2 & 3 & 4 & 1 & 2 & 3 & 4 & 1 & 2 & 3 & 4 & 1 & 2 & 3 & 4 \\
\hline $\begin{array}{c}\text { Pta. } \\
\text { Castillito }\end{array}$ & 0.08 & 0.10 & 0.03 & 0.05 & 2.33 & 2.68 & 3.98 & 3.90 & 1.18 & 0.40 & nd & nd & ns & ns & 387.50 & 250.00 & ns & ns & 3.23 & 3.15 & 0.70 & 0.63 & nd & nd \\
\hline $\begin{array}{c}\text { La } \\
\text { Escuelita }\end{array}$ & 0.13 & ns & 0.03 & 0.03 & 1.68 & ns & 3.90 & 3.58 & 0.85 & ns & nd & nd & $\mathrm{ns}$ & ns & 272.50 & 168.25 & ns & ns & 1.78 & 2.30 & 0.75 & ns & nd & 0.10 \\
\hline $\begin{array}{c}\text { Las } \\
\text { Canteras }\end{array}$ & ns & 0.10 & 0.03 & nd & ns & 2.05 & 3.25 & 3.13 & ns & 0.45 & nd & nd & ns & ns & 183.00 & 144.75 & ns & ns & nd & 2.95 & ns & 0.83 & 0.03 & nd \\
\hline
\end{tabular}

ns: no sample; nd: not detected; October 2003, January 2004, September 2004 and January 2005 (sampling 1, 2, 3 and 4, respectively) in the Corral Bay area, Valdivia, South Central Chile. Limit of detection (LD) in $\mu \mathrm{gg}^{-1}$ : As (0.001); $\mathrm{Cu}(0.20) ; \mathrm{Cr}(0.09) ; \mathrm{Fe}(0.25) ; \mathrm{Mn}(0.15) ; \mathrm{Pb}(0.10)$. 
n-alkanes in sediments of Las Coloradas, La Escuela and Corral Bay $\left(\mathrm{C}_{17} / \mathrm{Pri}<\right.$ 1 and $\left.\mathrm{C}_{18} / \mathrm{Phy}<1\right)$. Mussel TPH fingerprints showed weathered hydrocarbons resulting in a zone of increased concentration of alicyclic respect to aliphatic components (UCM), indicating the presence of petroleum hydrocarbons. No temporal variation in concentration of TPH-diesel found in sediments as well in mussels were observed except for samples collected during January 2004, due to a specific input of natural n-alkanes of different origin as compared to the first group, probably of diagenic and bacterial origin.

Low concentration and no seasonal variations for trace metals were found in mussels at each sampling point and a relatively even distribution among stations was observed. According to the Sediment Quality Guidelines (SQGs) developed for the National Status and Trends Program of the National Atmospheric and Oceanographic Administration (NOAA), the concentration levels of $\mathrm{Cu}$ and $\mathrm{As}$ in all sediment sampling points are above the "Effects Range-Low" (ERL), indicating that there may be a probable toxicity effect over the biota and attention must be paid on a moderate range of priority.

Finally, it is concluded in this study that there is a probable low to moderate pollution of the Corral Bay area according to the TPH-diesel and trace metals concentration levels found in sediments and Mytilus chilensis, however other pollutants, like fire retardants, organo-tin base antifoulings and pharmaceutical residues in liquid effluents of water treatment plants among many others, should be investigated as potential candidates that could explain mussel mortality.

\section{ACKNOWLEDGEMENTS}

This study was supported by the following sponsors: Office of Research and Development of the Universidad Austral de Chile (Grant S-200511) and Corral Bay Municipality-Universidad Austral de Chile Agreement No $130404-$ 01-EN/2004.

Thanks are given to Dr. Daisaku Ikeda, President of Soka Gakkai International for his continuous guidance and support on the protection of the environment and human life.

\section{REFERENCES}

1. U.S.EPA 2000. Guidance for Assessing Chemical Contaminant Data for Use in Fish Advisories. EPA 823-B-00-007.

2. P. Burban, W. Lick, and J. Lick. J. Geophys. Res. 49, 8323 (1989).

3. J.R. Chiarenzelli, R.J. Scrudato and M.L. Wunderlich. Environ. Sci. Technol. 31: 587-602 (1997).

4. R. Eisler in Handbook of Chemical Risk Assessment. Health Hazards to Humans, Plants and Animals. Vol. 1-2, Lewis Publishers, 2000; pp. $1500)$.

5. G.W. Johnson and R. Ehrlich. Environmental Forensic, 3, 59 (2002).

6. R. Morrison. Environmental Forensic, 1, 157 (2000).

7. Morrison R. Environmental Forensic, 1, 175 (2000).

8. D.A. Zemo. Environmental Forensic, 10, 229 (2009).

9. S.M. Mudge and C.G. Seguel. Mar. Pollut. Bull., 38, 1011 (1999)

10. R. Leeming, N. Bate, R. Hewlett and P.D. Nichols. Water Sci. Tecnol., 38, 15 (1998).

11. J. Hynynen, A. Palomäki, J.J. Meriläinen, A. Witick and K. Mäntikoski. J. Paleolim., 32, 351 (2004).

12. UNEP/IOC/IAEA. Determination of petroleum hydrocarbons in sediments. Reference Methods for Marine Pollution Studies $N^{\circ} 20$, UNEP, 1992).

13. R.D. Morrison and B.L. Murphy. Environmental Forensics. Elsevier Inc., pp.541, 2006.

14. V.G. Caccia, F.J. Millero, A. Palangues. Mar. Pollut. Bull., 46, 1420 (2003).

15. B. Zourarah, M. Maanan, M. Robin.. Environ. Chem. Lett, 7, 67, (2009).

16. J.W. Farrington, E.D. Goldberg, R.W. Risebrough, J.H. Martin, V.T. Bowen. Environ. Sci. Technol., 17,490 (1983).

17. SCHER, Opinion on risk arising from the use of copper-based antifouling paints used in leisure boating. Dutch notification 2003/0201/ NL, Scientific Commitee on Health and Environmental Risks. Health Consumer Protection, European Comission, 30 January 2007.

18. H. Palma-Fleming, C. Cornejo, Myriam Gonzalez, V. Pérez, Marta González, E. Gutierrez, J.L. Sericano, M. Seeger. J. Chil. Chem. Soc. 53, 1533 (2008).

19. H. Palma-Fleming, A.J. Asencio and E. Gutierrez. J. Environ. Monit., 6, 229 (2004).

20. U.S.EPA. Methods for Collection, Storage and Manipulation of
Sediments for Chemical and Toxicological Analysis: Technical Manual. EPA-823-B-01-002. U. S. Environmental Protection Agency, Office of Water, Washington, DC (2001).

21. U.S.EPA. Method 3570-9. Microscale Solvent Extraction (MSE). SW846. Test Methods for Evaluating Solid Wastes. Physical Chemical methods. U. S. Environmental Protection Agency (2002).

22. K. Granby and N.H. Spliid. Mar.Pollut. Bull., 30, 74 (1995).

23. U.S.EPA. Method 8270C. Semivolatile Organic Compounds by Gas Chromatography/Mass Spectrometry (GC-MS). SW-846 Test Methods for Evaluating Solid Wastes. Physical Chemical methods. U. S. Environmental Protection Agency (1996).

24. Zang Z., Yang M., Pawliszyn J. Anal. Chem., 66, 844 A (1994).

25. U.S.EPA. Method 3510C. Separatory Funnel Liquid-liquid Extraction. SW-846 Test Methods for Evaluating Solid Wastes. Physical Chemical methods. U. S. Environmental Protection Agency (1996).

26. U.S.EPA. Method 823-B-002. SW-846 Test Methods for Evaluating Solid Wastes. Physical Chemical methods. U. S. Environmental Protection Agency (2001).

27. J. Schwarzbauer, M. Ricking, S. Franke and W. Francke. Environ. Sci. Technol., 35, 4015 (2001).

28. F.J. Di Carlo, J. Seifter, V.J. DeCarlo. Environ. Health Perspect. 23 , 351 (1978)

29. M.U. Beg, T. Sabed, S. Al-Muzaini, K.R. Beg and M. Al-Bahloul. Ecotoxicol. and Environ. Safety, 54, 47 (2003).

30. J.C. Colombo, A. Barreda, C. Bilos, N. Cappelletti, S. Demichelis, P. Lombarda, M.C. Migota, C. Skorupka and G. Suárez. Environ. Pollut., 134, 277 (2005).

31. C.J. Schubert, R. Stein. Mar. Geol., 138, 11 (1997).

32. G.C. Cripps. Antartic Sci., 1, 307 (1989).

33. M. G. Commendatore, J.L. Esteves, J.C. Colombo. Mar. Pollut. Bull., 40, 989 (2000)

34. J.C. Colombo, N. Cappelletti, M.C. Migiya, E. Speranza. Chhemosphere, 68, 2128 (2007).

35. G. Liebezeit and R. Wöstmann. Bull. Environ. Contam. Toxicol., 83, 403 (2009).

36. R.Amodio-Cocchieri, T. Cirillo. Mar. Pollut. Bull., 46, 362 (2003).

37. M.A. Haiqing, Q. Song, X. Wang. Chinese J. of Oceanol. and Limnol., 27, 887 (2009)

38. R. Marzi, B.E. Torkelson, R.K. Olson. Org. Geochem., 20, 1303 (1993).

39. H.L. Ten Haven, J. Rullkötter, J.W. De Leeuw and J.S. Sinninghe Damsté. Nature 333, 604 (1988).

40. C. Reddy and J.G. Quinn. Mar. Pollut. Bull., 38, 126 (1999).

41. M. Meniconi and I. Gabardo. Environ. Forensics, 3: 303 (2002).

42. J. Volkman,D. Holdsworth, G. Neill, H. Bavor. The Sci. of the Total Environ., 11, 203 (1992).

43. J.C. Colombo, E. Pelletier, Ch. Brochu, M. Khall. Environ. Sci. Technol., 23, 888 (1989)

44. Z. Wang, M. Fingas and D,S. Page. J. Chromatogr. A, 843, 369 (1999).

45. T.M. Tavares, V.C. Rocha, C. Porte, D. Barceló and J. Albaigés. Mar. Pollut. Bull., 19, 575 (1988).

46. R.S. Carreira, P.V. Ribeiro, C.E.M. Silva and C.O. Farías. Ouimica Nova, 32, 1805 (2009).

47. K.A. Burns and J.L. Nsiths. Distribution of Petroleum Hydrocarbons in Westernport Bay (Australia): Results of Chronic Low Level Inputs. In: Wolfe, D. (Ed.), Fate and Effects of Petroleum Hydrocarbons in Marine Ecosystems and Organinss. Pergamon, New York, pp. 442-453.

48. P.D. Boehm and J.G. Quinn. Mar. Biol., 44, 227 (1977).

49. M.Soler, G.T. Grimalt and J. Albaiges. Chemosphere, 18, 1809 (1989).

50. R. Amodio-Cocchieri and T. Cirillo. Mar. Pollut. Bull., 46, 362 (2003).

51. E.S. Gilfillan and J.H. Vandermeulen. J. Fish. Res. Board Can., 35, 630 (1978).

52. S. Wei, R.K.F. Lau, C.N. Fung, G.J. Zheng, J.C.W. Lam, D.W. Connell, Z. Fang, B.J. Richardson and P.K.S. Lam. Mar. Pollut. Bull., 52, 1682 (2006).

53. NRC. Contaminated Marine Sediments-Assessment and Remediation. National Research Council. National Academic Press, Washington, DC, $493 \mathrm{pp}$.

54. D.S. Miller. Env. Toxicol. and Chem., 1, 39 (1982).

55. M. Sanders, S. Sivertsen and G. Scott. Arch. Of Environ. Cont. And Toxicol., 43, 438 (2002).

56. U.S.EPA 2000. Guidance for Assessing Chemical Contaminant Data for Use in Fish Advisories. EPA 823-B-00-007.

57. A. Scarlett, T. Galloway, S.J. Rowland. J. Soils Sediments, 7, 200 (2007). 
58. J.J. Stegeman and J.M. Teal. Marine Biology, 22, 37 (1973).

59. S. Bhattacharyya, P.L. Klerks and J.A. Nyman. Environ. Pollut., 122, 205 (2003)

60. U.S.EPA 1991. Criteria for sediment concentration of metals in: Heavy metals contamination of sediments in the upper connecting channels of Great Lakes, Hydrobiology 219, 307.

61. NOAA. Sediment Quality Guidelines developed for the National Status and Trends Program. National Oceanic and Atmospheric Administration (NOAA), 1999, $12 \mathrm{p}$

62. L.K.P. Martins, I.A. Nascimento, G. Fillmann, R. King, A.J.A. Evangelista, J.W. Readman, M.H. Depledge. Environ Res., 99, 387 (2005).

63. M.S. Astorga España, E.M. Peña Méndez, O. Lecaros Palma and F.J. García Montelongo. Mar. Pollut. Bull., 36, 542 (1998).

64. P. Yeast, F. Gagné and J. Hellou. Environ. Int., 34, 254 (2008).
65. W.X. Liu, J.L. Chen, X.M. Lin, Y.S. Fan and S. Tao. Environ Pollut, 146, 470 (2007)

66. H. Palma-Fleming, E. Quiroz, E. Gutierrez, E. Cristi, B. Jara, M.L. Keim, M. Pino, A. Huber, E. Jaramillo, P. Quijón, H. Contreras and C. Ramirez. Bol. Soc. Chil. Quím., 45, 551 (2000).

67. C.K. Yap, A. Insail and S.G. Tan. Food Chem. 84, 569 (2004).

68. G.W. Bryan and W.J. Langston. Environmental Pollution, 76, 89 (1992).

69. H.D. Bhattarai, B. Paudel, N.S. Park, K.S. Lee, H.W. Shin. J. of Environ. Biol. 28, 857 (2007)

70. L. Tóth, M. Juhász, T. Varga, A. Csikkel-Szolnoki and J. Nemcsók. J. Environ. Sci. Health Part B-Pest. Food Cont. and Agric. Wastes, 31, 627 (1996).

71. H.S. Lodhi, M.A. Kahn, R.S. Verma and U.D. Sharma. Journal of Environmetal Biology, 27, 585-588 (2006). 